\title{
EFFECTS OF A SECOND-ENTRY PRESCRIBED FIRE IN A MIXED CONIFER FOREST
}

\author{
Daniel C. Laughlin ${ }^{1}$, John Paul Roccaforte ${ }^{2}$, and Peter Z. Fulé3
}

\begin{abstract}
We analyzed the effects of a second-entry prescribed fire in a mixed conifer forest in Grand Canyon National Park, Arizona, 14 years after the initial burn to assess whether restoration and management objectives were achieved. The surface fire had little effect on large overstory ponderosa pine, Douglas-fir, and white fir trees and did not change total tree density or basal area. The fire reduced the overall density of conifer seedlings $<30 \mathrm{~cm}$ tall by $87 \%$, but had a smaller effect on seedlings $>30 \mathrm{~cm}$ tall and on sapling density. The fire reduced litter depths by $33 \%$, duff depths by $23 \%$, fine woody debris by $21 \%$, and coarse woody debris by $44 \%$. These effects were mostly consistent with restoration goals in mixed conifer forests and continue to move this forest toward reference conditions. Grand Canyon National Park staff now considers this forest to be in "maintenance burning," meaning that they plan to allow natural ignitions to maintain forest structure in the future. This forest is now more resilient to projected increases in fire size and/or frequency under conditions of a warming climate. This example illustrates that use of prescribed fire in a ponderosa pine-dominated mixed conifer forest can be consistent both with restoring historical conditions and with managing for resilience under altered disturbance regimes accompanying a changing climate.
\end{abstract}

RESUMEN.-Analizamos los efectos de una quema prescrita que se realizó por segunda vez 14 años después de la quema inicial en un bosque templado de coníferas en el Parque Nacional del Gran Cañón en Arizona, para evaluar si las metas de restauración y manejo se lograron. El incendio en la superficie casi no afectó los pinos ponderosa de alto dosel, los abetos de Douglas ni los abetos del Colorado, y no cambió la densidad total de árboles o el área basal. El fuego redujo en un 87\% la densidad total de las plántulas de coníferas de $<30 \mathrm{~cm}$ de altura, pero tuvo un impacto menor en las plántulas de $>30 \mathrm{~cm}$ de altura y en la densidad de los árboles jóvenes. El fuego redujo en un $33 \%$ la profundidad de la hojarasca, en un $23 \%$ la profundidad de la capa de fermentación, en un $21 \%$ el detritus leñoso fino y el grueso en un $44 \%$. Estos efectos fueron en su mayoría consistentes con las metas de restauración para los bosques mixtos de coníferas y continúan impulsando este bosque hacia sus condiciones de referencia. Ahora, el personal del Parque Nacional del Gran Cañón considera que este bosque está en "quemas de mantenimiento", queriendo decir con esto que planean permitir incendios naturales para mantener la estructura forestal en el futuro. En este momento, este bosque se encuentra más fuerte para resistir los aumentos proyectados en la magnitud y frecuencia de los incendios derivados de condiciones climáticas que serán más calurosas. Este ejemplo ilustra que el uso de la quema prescrita en un bosque mixto de coníferas dominado por pinos ponderosa puede ser consistente tanto con la restauración de las condiciones históricas como con el manejo para la resistencia a regímenes de perturbaciones alteradas por el cambio climático.

Montane forests across western North America have become increasingly dense over the last century due to a variety of factors, including grazing, logging, suppression of frequent fires, and climatic events favoring conifer regeneration (Allen et al. 2002). Efforts to restore these ecosystems often involve thinning small-diameter trees and reintroducing fire. In some cases, however, tree thinning is very difficult, especially in national parks, where the felling of trees with chainsaws is kept to a minimum. In these cases, fire is the best tool available to forest managers interested in restoring historical fire regimes and forest structure over broad spatial scales. Multiple prescribed fires are often needed to achieve long-term management objectives, but little information is available to managers about the effects of second-entry burns in mixed conifer forests.

Fulé et al. (2004) assessed whether relatively intense burning could be used to restore the historical fire regime and forest structure in a mixed conifer forest in Grand Canyon National Park (GCNP), Arizona. In 1993, a prescribed fire in a dense forest in GCNP escaped prescription and burned with greater intensity and severity than anticipated (although the fire remained within the proposed boundaries). The fire reduced average tree density to 331 trees . $\mathrm{ha}^{-1}$ and basal area to $29 \mathrm{~m}^{2} \cdot \mathrm{ha}^{-1}$ (compared

${ }_{1}^{1}$ Department of Biological Sciences, University of Waikato, Private Bag 3105, Hamilton 3240, New Zealand. E-mail: d.laughlin@waikato.ac.nz
${ }^{2}$ Ecological Restoration Institute, Northern Arizona University, Box 15017, Flagstaff, AZ 86011.

${ }^{2}$ Ecological Restoration Institute, Northern Arizona University, Box 15017, Flags
${ }^{3}$ School of Forestry, Northern Arizona University, Box 15018, Flagstaff, AZ 86011. 
to similar unburned forest with a density of 940 trees $\cdot \mathrm{ha}^{-1}$ and basal area of $41 \mathrm{~m}^{2} \cdot \mathrm{ha}^{-1}$ ), values which are similar to pre-European reference conditions (approximately 246 trees $\cdot \mathrm{ha}^{-1}$ and $29 \mathrm{~m}^{2} \cdot \mathrm{ha}^{-1}$; Fulé et al. 2004). Mortality was concentrated in fire-susceptible species, especially white fir, restoring dominance by fire-resistant ponderosa pine. The native herbaceous understory also responded positively to this intense fire (Huisinga et al. 2005). Fulé et al. (2004) concluded that, although the intentional use of severe burning is challenging to managers because of the increased risk of escaped fires, the ecological outcome of this fire was consistent with ecological restoration goals for mixed conifer forests.

Managers at Grand Canyon National Park have continued to utilize fire, mimicking natural fire events in frequent-fire forests, to restore historical forest structure and processes. In 2007, GCNP fire staff reburned the same mixed conifer forest stand that burned in 1993. The overall goal of the second-entry fire was to maintain old-growth forest structure so that the forest could tolerate low-intensity surface fires. Specific management objectives included (1) minimizing mortality of large trees, (2) maintaining low seedling and sapling densities, and (3) further reducing surface fuel loadings. In this note, we assess whether this second-entry prescribed fire resulted in meeting these 3 objectives. An objective was considered to be successfully met if (1) densities of large trees were not significantly reduced, (2) seedling and sapling densities were significantly reduced, and (3) fuel loads were significantly reduced.

This study was conducted in a mixed conifer forest on Swamp Ridge, Kaibab Plateau, in northern Arizona $\left(36^{\circ} 20^{\prime} \mathrm{N}, 112^{\circ} 15^{\prime} \mathrm{W}\right)$. Dominant tree species in the forest included ponderosa pine (Pinus ponderosa C. Lawson), white fir (Abies concolor [Gord. \& Glend.] Lindl. ex Hildebr.), Douglas-fir (Pseudotsuga menziesii [Mirb.] Franco), Engelmann spruce (Picea engelmannii Parry ex Engelm.), and quaking aspen (Populus tremuloides Michx.). Elevation ranged from $2427 \mathrm{~m}$ to $2549 \mathrm{~m}$. Long-term average annual precipitation at the North Rim ranger station (elevation $2564 \mathrm{~m}$ ) is $65 \mathrm{~cm}$; average annual snowfall is $356 \mathrm{~cm}$. Temperatures range from an average July maximum of $25^{\circ} \mathrm{C}$ to an average January minimum of $-8{ }^{\circ} \mathrm{C}$ (Western Regional Climate Center, http://www.wrcc dri.edu).
Before 1879, the fire regime in this forest was one of frequent surface fires, often covering large areas. The Weibull median probability interval between surface fires was 8.7 years for fires scarring $25 \%$ or more of fire-scarred sample trees (Fulé et al. 2003). After the 1879 fire, no large fire was recorded on the site (Fulé et al. 2003). The elimination of surface fires after 1879 was most likely the result of (1) heavy grazing by domestic livestock introduced by European settlers (Altschul and Fairley 1989), which removed herbaceous fuels, and (2) fire suppression policies when the area was set aside as a reserve in 1893 and then a national park in 1919 (Fulé et al. 2003).

Previously described by Fulé et al. (2004), a 490-ha unit called "Northwest 3" was ignited by Grand Canyon National Park staff in 1993 in this mixed conifer forest (Fig. 1). This same unit was burned again using prescribed fire from 8 to 11 November 2007. Strip head and backing fires were hand-ignited with drip torches on the perimeter of the unit, and the interior was burned via aerial ignitions. Weather was conducive to moderate burning: skies were partly cloudy, winds were light from the southwest, relative humidity ranged from $21 \%$ to $49 \%$, and maximum air temperatures ranged from 10 to $15^{\circ} \mathrm{C}$. Fuel moistures ranged between $4 \%$ and $20 \%$ across all size classes. Flame lengths averaged $3-15 \mathrm{~cm}$ in needle fuels and $90 \mathrm{~cm}$ in grass fuels, with flames creeping up the bark to heights of $6 \mathrm{~m}$ in live, mature pines and firs. Isolated group and single-tree torching was observed occasionally, and standing snags and coarse fuels burned actively into the nights.

We remeasured all thirty 0.1 -ha plots from 20 to 25 June 2008 to assess fire effects. We recorded (1) species, condition (live or snag), and diameter at breast height (dbh) of all trees $>15 \mathrm{~cm}$ dbh on the entire plot and on all trees between $2.5 \mathrm{~cm}$ and $15 \mathrm{~cm} \mathrm{dbh}$ on a $250-\mathrm{m}^{2}$ subplot; (2) seedling (trees $<2.5 \mathrm{~cm}$ dbh) densities of all species on a $50-\mathrm{m}^{2}$ subplot; and (3) fuel loadings on four 15.24-m planar intersect transects placed in random directions every $10 \mathrm{~m}$ along the plot centerline. Litter (undecomposed material) and duff (decomposing material or humus) depths were measured every $1.52 \mathrm{~m}$ along each transect. Woody debris was recorded by timelag/size classes, where timelag refers to the average time needed for the debris to come into equilibrium with atmospheric moisture content. Fine woody debris 


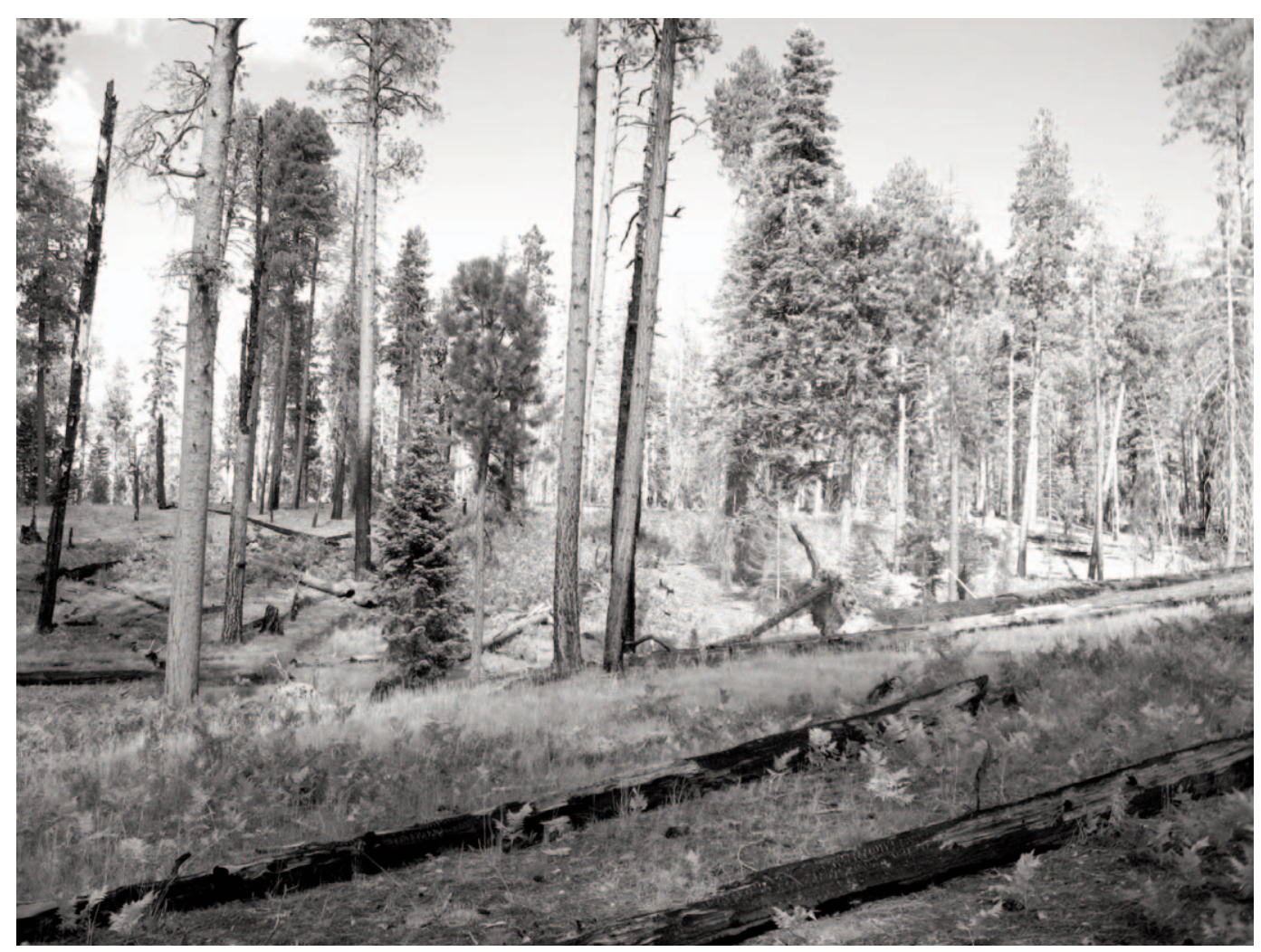

Fig. 1. Open forest conditions in a never-harvested mixed conifer forest in Grand Canyon National Park, Arizona. This forest (the "Northwest 3" unit) has been burned with prescribed fire twice (1993 and 2007) by park staff after nearly 114 years of fire exclusion. Note the productive understory of graminoids and western bracken fern, the presence of snags and coarse woody debris with high wildlife value, and the high crown base heights of large trees. This forest is now more resilient to projected increases in fire sizes and/or frequencies under conditions of a warming climate. Photo: J.P. Roccaforte.

(FWD) consisted of the sum of 1-hour (woody fuels $>0 \mathrm{~cm}$ and $<0.64 \mathrm{~cm}$ in diameter), 10-hour $(0.64-2.54 \mathrm{~cm})$, and 100-hour $(2.54-7.62 \mathrm{~cm})$ fuels. Coarse woody debris (CWD) consisted of the sum of both sound and rotten woody debris $>7.62 \mathrm{~cm}$ in diameter. A more detailed account of plot-sampling methods can be found in Fulé et al. (2004).

We analyzed fire effects as a before-after study design (van Mantgem et al. 2001) by subtracting data collected 8 years before the recent fire (1999) from data collected immediately following the fire (2008). Thus, changes between 1999 and 2008 reflect net changes of forest growth plus ingrowth of new trees minus natural and fire-induced mortality. Natural (e.g., drought-induced) mortality was likely $6 \%-11 \%$ of the mortality in this stand, based on evidence from nearby stands (Fulé and Laughlin 2007). We acknowledge that these data may underestimate fire-induced mortality because we remeasured stands only one year after the fire. Given evidence from nearby sites, it is possible to observe an additional 5\%-30\% more mortality, depending on size class and species (Fulé and Laughlin 2007). However, delayed mortality is likely low in this forest due to the high crown base heights resulting from the previous burn. Unfortunately, resources for remeasurement 2 years after the fire were unavailable. The calculated differences were analyzed with a Wilcoxon's signed-ranks test (a nonparametric alternative to the paired $t$ test) to determine whether these changes were significantly different than zero. Fulé et al. (2004) were able to compare fire effects in the Northwest 3 unit to a nearby unburned control, but we could not remeasure this site to use as a control since it was burned by a wildland fire in 2003. Nevertheless, we report stand structural attributes of this control 
TABLE 1. Assessment of management objectives after a November 2007 prescribed fire in a mixed conifer forest on the North Rim of Grand Canyon National Park (Arizona, USA). Values reported are means followed by standard errors in parentheses. Asterisks indicate level of significance of the Wilcoxon's signed-ranks test $(* P<0.05$, $* * P<0.01$, *** $P<0.001$, *****:P$<0.0001, \mathrm{NS}=$ not significant).

\begin{tabular}{|c|c|c|c|c|c|}
\hline Forest structural attributes & $\begin{array}{l}\text { Control } \\
(1999)^{\dagger}\end{array}$ & $\begin{array}{l}\text { Prefire } \\
(1999)\end{array}$ & $\begin{array}{l}\text { Postfire } \\
(2008)\end{array}$ & $\begin{array}{l}\% \text { Change from } \\
\text { pre- to postfire } \neq\end{array}$ & $\begin{array}{l}\text { Objective } \\
\text { met? }\end{array}$ \\
\hline \multicolumn{6}{|c|}{ OBJECTIVE 1: LIMIT LARGE (>40 CM DBH) TREE MORTALITY } \\
\hline Large ponderosa pine density & $51(5)$ & $48(7)$ & $44(7)$ & $8 \%$ reduction, $\mathrm{NS}$ & Yes \\
\hline Large Douglas-fir density & $4(2)$ & $2(1)$ & $2(1)$ & $0 \%$ reduction, NS & Yes \\
\hline Large white fir density & $29(3)$ & $10(11)$ & $10(11)$ & $0 \%$ reduction, $\mathrm{NS}$ & Yes \\
\hline \multicolumn{6}{|c|}{ OBJECTIVE 2: REDUCE DENSITY OF CONIFER SEEDLINGS (TREES < 2.5 CM DBH) AND SAPLINGS (TREES 2.5-15 CM DBH) } \\
\hline Total conifer seedlings (<30 cm height) & $2478(700)$ & $4160(1418)$ & $548(216)$ & $87 \%$ reduction $* * * *$ & Yes \\
\hline Ponderosa pine seedlings $(<30 \mathrm{~cm})$ & $54(26)$ & $174(52)$ & $67(36)$ & $61 \%$ reduction $*$ & $\S$ \\
\hline White fir seedlings $(<30 \mathrm{~cm})$ & $2397(691)$ & $3336(1371)$ & $354(155)$ & $89 \%$ reduction $* * * *$ & $\S$ \\
\hline Douglas-fir seedlings (<30 cm) & $27(21)$ & $402(215)$ & $34(22)$ & $91 \%$ reduction $*$ & $\S$ \\
\hline Engelmann spruce seedlings $(<30 \mathrm{~cm})$ & $0(0)$ & $167(147)$ & $94(94)$ & $44 \%$ reduction, NS & $\S$ \\
\hline Subalpine fir seedlings $(<30 \mathrm{~cm})$ & $0(0)$ & $80(80)$ & $0(0)$ & $100 \%$ reduction, NS & $\S$ \\
\hline Aspen seedlings $(<30 \mathrm{~cm})$ & $2185(629)$ & $1444(542)$ & $154(116)$ & $89 \%$ reduction $* * * * *$ & $\S$ \\
\hline Total conifer seedlings (>30 cm height) & $1060(307)$ & $495(246)$ & $422(210)$ & $15 \%$ reduction, NS & No \\
\hline Ponderosa pine seedlings $(>30 \mathrm{~cm})$ & $41(18)$ & $20(15)$ & $20(12)$ & No change, NS & $\S$ \\
\hline White fir seedlings $(>30 \mathrm{~cm})$ & $999(301)$ & $261(123)$ & $301(145)$ & $15 \%$ increase, NS & $\S$ \\
\hline Douglas-fir seedlings (>30 cm) & $20(15)$ & $7(7)$ & $14(9)$ & $100 \%$ increase, NS & $\S$ \\
\hline Engelmann spruce seedlings $(>30 \mathrm{~cm})$ & $0(0)$ & $160(160)$ & $87(87)$ & $46 \%$ reduction, NS & $\S$ \\
\hline Subalpine fire seedlings $(>30 \mathrm{~cm})$ & $0(0)$ & $47(47)$ & $0(0)$ & $100 \%$ reduction, NS & $\S$ \\
\hline Aspen seedlings $(>30 \mathrm{~cm})$ & $675(344)$ & $702(233)$ & $0(0)$ & $100 \%$ reduction $* * *$ & $\S$ \\
\hline Total conifer saplings $(2.5-15 \mathrm{~cm}$ dbh) & $417(72)$ & $138(35)$ & $119(30)$ & $14 \%$ reduction, NS & No \\
\hline Ponderosa pine saplings & $55(15)$ & $39(16)$ & $24(8)$ & $39 \%$ reduction, NS & $\S$ \\
\hline White fir saplings & $320(63)$ & $72(21)$ & $75(20)$ & $4 \%$ increase, NS & $\S$ \\
\hline Douglas-fir saplings & $42(18)$ & $17(9)$ & $8(6)$ & $3 \%$ reduction, NS & $\S$ \\
\hline Engelmann spruce saplings & $0(0)$ & $9(8)$ & $12(11)$ & $33 \%$ increase, NS & $\S$ \\
\hline Aspen saplings & $175(58)$ & $35(24)$ & $33(21)$ & $3 \%$ reduction, NS & $\S$ \\
\hline \multicolumn{6}{|c|}{ OBJECTIVE 3: REDUCE FOREST FLOOR FINE AND COARSE WOODY FUEL LOADS } \\
\hline Litter depth $(\mathrm{cm})$ & $0.4(0.05)$ & $0.6(0.04)$ & $0.4(0.04)$ & $33 \%$ reduction $*$ & Yes \\
\hline Duff depth $(\mathrm{cm})$ & $3.6(0.3)$ & $1.3(0.1)$ & $1.0(0.1)$ & $23 \%$ reduction $* *$ & Yes \\
\hline Fine woody debris $\left(\mathrm{mg} \cdot \mathrm{ha}^{-1}\right)$ & $13.2(1.2)$ & $6.1(0.7)$ & $4.8(0.4)$ & $21 \%$ reduction, $\mathrm{NS}$ & No \\
\hline Coarse woody debris $\left(\mathrm{mg} \cdot \mathrm{ha}^{-1}\right)$ & $91.5(14.2)$ & $49.6(7.3)$ & $28.0(3.7)$ & $44 \%$ reduction $* * *$ & Yes \\
\hline
\end{tabular}

†Control data represent forest structure in a similar nearby mixed conifer forest that was unburned in 1999. These data illustrate what forest conditions were like in the Northwest 3 unit before the first prescribed fire (originally reported in Fulé et al. 2004). Tree densities and fuel loads were very high in this control unit because the forest had not burned for 114 years.

\$Percent change from before the second-entry fire ('Prefire [1999]') to after the second-entry fire ('Postfire [2008]') represents stand-level average changes in each forest structural attribute.

$\S$ Management objectives for individual species were not considered in the burn plan by national park staff. Objectives were for conifer species in aggregate because it is not possible to implement a landscape-scale fire that preferentially kills only certain species. Aspen seedlings were not targeted in the burn, yet data suggest aspen seedlings were especially susceptible to fire-induced mortality

area in 1999 in Table 1 to give an impression of how the 2 prescribed fires in the Northwest 3 unit have restored overall forest structure.

The prescribed fire had minimal impact on the overstory (Table 1, Fig. 1). Large $(>40 \mathrm{~cm}$ $\mathrm{dbh}$ ) ponderosa pine tree mortality was limited to a nonsignificant $8 \%$ reduction. Large Douglas-fir and white fir trees survived the fire. Total overstory basal area $(P=0.20)$ and density $(P=0.43)$ did not greatly change. Ponderosa pine densities (inclusive of all size classes) declined significantly from 136 to 125 trees $\cdot \mathrm{ha}^{-1}$ $(P=0.01)$, but pine basal area was not significantly reduced $(P=0.71)$, indicating that mortality was more pronounced in smaller-diameter pines. No other species exhibited significant changes in basal area or density. These results were consistent with GCNP's management objectives to retain large trees (Table 1).

Our assessment of tree mortality was conducted one year after the fire, but sometimes mortality is delayed following fire in mixed conifer forest. Fulé and Laughlin (2007) observed that $92 \%$ of large $(>40 \mathrm{~cm})$ trees in a nearby mixed conifer forest that survived the first year after a severe fire survived to the second year after the fire. We therefore expect that, at a minimum, $92 \%$ of the large trees in this study that survived the first year after the lowintensity surface fire ultimately survived the fire. 
The prescribed fire had significant impacts on tree regeneration (Table 1). Total densities of conifer seedlings $<30 \mathrm{~cm}$ tall declined significantly by $87 \%$ (Table 1 ). We detected significant reductions in ponderosa pine, white fir, Douglasfir, and aspen seedlings $<30 \mathrm{~cm}$ tall. Aspen was the only species with seedlings (i.e., sprouting ramets) $>30 \mathrm{~cm}$ tall that exhibited significant mortality. Similarly, the fire had little effect on sapling densities (Table 1). Our observation that significant mortality of understory strata was limited to seedlings $<30 \mathrm{~cm}$ tall further substantiates the claim that mortality of large trees was minimal. The large reductions in the smallest seedling size class was consistent with management objectives, but park managers would have preferred to see greater reductions in the larger seedling size class and sapling densities. The reduction in live conifer seedlings will help to maintain the desired open-forest conditions, and the density of established seedlings and saplings are well within the range needed to sustain a ponderosa pine forest (Bailey and Covington 2002). Although aspen recruitment was significantly reduced, we expect aspen regeneration to continue to flourish, given aspen's tendency to sprout vigorously following fire.

The prescribed fire had significant impacts on fuel loadings (Table 1). Forest floor litter and duff depths were significantly reduced by $33 \%$ and $23 \%$, respectively. Total fine woody debris declined by $21 \%$, but this reduction was not significant and did not meet desired objectives. Total coarse woody debris significantly declined by $44 \%$, thereby meeting the management objective for this fuel type. These reductions in fuel loadings will reduce the intensity of fires in the short term. Forest floor depths will steadily rise as senesced leaves are annually cast onto the ground.

Despite the fact that a few specific objectives were not met (Table 1), land managers in GCNP feel that these fires achieved their overall restoration goals and now consider this forest to be in "maintenance burning," meaning that they plan to allow natural ignitions to maintain forest structure in the future (Fig. 1). This is a major accomplishment, considering that this forest was susceptible to crown ignition and spread prior to the first fire in 1993 (Fule et al. 2004). However, given the large reduction in aspen regeneration observed, aspen stands may need to be protected from repeated prescribed fire if the stands are ever to reach maturity.
This protection may be counter to the goals of restoring a frequent fire regime, but national park staff are often charged with managing for multiple resource objectives.

The use of historical (or pre-Euro-American settlement) ecosystem structure as a target for ecological restoration has been justifiably questioned in light of observed and projected changes in climate (Harris et al. 2006). Why restore historical ecosystems if they persisted in a climate that no longer exists? Ecosystems, specifically those in western North America, are projected to become increasingly hotter and drier over the next century (Seager et al. 2007), thereby increasing the probability of larger, more frequent wildfires (McKenzie et al. 2004). Climate change projections are prompting land managers to consider strategies for promoting resilience in the face of climate stressors and climate-induced changes to disturbance regimes (Dale et al. 2001). Given observed temperature increases over the last century and future projections of increased warming (IPCC 2007), it may seem counterintuitive to continue to use historical conditions as a reference for restoration (Harris et al. 2006, Millar and Brubaker 2006). However, it was recently argued that restoration of historical fire regimes in forests that were adapted to frequent fires can still be consistent with climate-change expectations. If fires are predicted to increase in size and frequency, then it is still logical to reduce the susceptibility of these forests to standreplacing fires through restoration treatments (Fulé 2008). In particular, restoration treatments in upper elevation ecotones (e.g., montane mixed conifer forests) may be valuable for facilitating forest migration and promoting resilience to a changing disturbance regime.

Where fuel conditions and management policy permit, fire use in pine-dominated mixed conifer forests is consistent both with restoring historical reference conditions and with managing for resiliency under altered disturbance regimes accompanying a changing climate. The second-entry fire made this mixed conifer stand less susceptible to severe, stand-replacing fires, and this result is a positive management outcome, whether future climate is similar to recent history or whether it is warmer and drier. Second-entry fire would likely have similar results in ecosystems not included in this study, including Douglas-fir-invaded ponderosa pine forests in the northern Rocky Mountains, 
mixed conifer forests in the Sierra Nevada, southeastern longleaf pine forests, and other forest systems where frequent surface fires historically played a significant role.

We thank Grand Canyon National Park staff Windy Bunn (Fire Ecologist), Dave Robinson (Fuels Specialist and Firing Boss), and Chris Marks (Deputy Fire Management Officer) for their comments on this manuscript. This study was supported by funding to the Ecological Restoration Institute from the USDA Forest Service.

\section{Literature Cited}

Allen, C.D., M. Savage, D.A. Falk, K.F. Suckling, T.W. Swetnam, T. Schulke, P.B. Stacey, P. Morgan, M. Hoffman, and J.T. Klingel. 2002. Ecological restoration of southwestern ponderosa pine ecosystems: a broad perspective. Ecological Applications 12:1418-1433.

Altschul, J.H., AND H.C. FAIRLEy. 1989. Man, models, and management: an overview of the archaeology of the Arizona Strip and the management of its cultural resources. USDA Forest Service and USDI Bureau of Land Management Report Contract 53-8371-6-0054, Dames and Moore, Phoenix, AZ.

BAILEy, J.D., AND W.W. Covington. 2002. Evaluating ponderosa pine regeneration rates following ecological restoration treatments in northern Arizona, USA. Forest Ecology and Management 155:271-278.

Dale, V.H., L.A. Joyce, S. McNulty, R.P. Neilson, M.P. Ayres, M.D. Flannigan, P.J. Hanson, L.C. Irland, A.E. Lugo, C.J. Peterson, ET AL. 2001. Climate change and forest disturbances. BioScience 51:723-734.

FulÉ, P.Z. 2008. Does it make sense to restore wildland fire in changing climate? Restoration Ecology 16:526-531.

Fulé, P.Z., A.E. Cocke, T.A. Heinlein, AND W.W. CovINGTON. 2004. Effects of an intense prescribed forest fire: is it ecological restoration? Restoration Ecology 12:220-230.

Fulé, P.Z., T.A. Heinlein, W.W. Covington, and M.M. Moore. 2003. Assessing fire regimes on Grand Canyon landscapes with fire-scar and fire-record data. International Journal of Wildland Fire 12:129-145.

Fulé, P.Z., And D.C. Laughlin. 2007. Wildland fire effects on forest structure over an altitudinal gradient, Grand Canyon National Park, USA. Journal of Applied Ecology 44:136-146.

Harris, J.A., R.J. Hobbs, E. Higgs, and J. Aronson. 2006. Ecological restoration and global climate change. Restoration Ecology 14:170-176.

Huisinga, K.D., D.C. Laughlin, P.Z. Fulé, J.D. SpRinger, AND C.M. MCGLONE. 2005. Effects of an intense prescribed fire on understory vegetation in a mixed conifer forest. Journal of the Torrey Botanical Society 132:590-601.

[IPCC] Intergovernmental Panel on Climate Change. 2007. Climate change 2007: the physical science basis. Contribution of Working Group I to the Fourth Assessment Report of the IPCC, Cambridge University Press, Cambridge, United Kingdom.

McKenzie, D., Z. Gedalof, D.L. Peterson, and P. Mote. 2004. Climatic change, wildfire, and conservation. Conservation Biology 18:890-902.

Millar, C.I., and L.B. Brubaker. 2006. Climate change and paleoecology: new contexts for restoration ecology. Pages 315-340 in D.A. Falk, M.A. Palmer, and J.B. Zedler, editors, Foundations of restoration ecology. Island Press, Washington, DC.

Seager, R., M. Ting, I. Held, Y. Kishnir, J. Lu, G. Vecchi, H.-P. Huang, N. Harnik, A. LeetmaA, N.-C. LaU, et AL. 2007. Model projection of an imminent transition to a more arid climate in southwestern North America. Science 316:1181-1184.

Van Mantgem, P., M. Schwartz, and M. Keifer. 2001. Monitoring fire effects for managed burns and wildfires: coming to terms with pseudoreplication. Natural Areas Journal 21:266-273.

Received 15 February 2011 Accepted 9 August 2011 